\title{
Scientific and Methodological Approaches to the Evaluation of Marketing Management of Enterprises in the Context of International Diversification
}

\author{
By Alona Tanasiichuk ${ }^{1}$, Olha Hromova ${ }^{2}$, Svetlana Kovalchuk ${ }^{3}$, Iryna Perevozova ${ }^{4}$, \\ Oleg Khmelevskyi ${ }^{5}$
}

\begin{abstract}
Marketing management of business activities in the context of international diversification involves the construction of an appropriate system of information gathering, study of foreign markets, planning, implementation and control of the marketing program, risk and profit assessment, effectiveness of marketing decisions, development of marketing strategy of the enterprise, which allows obtaining the maximum positive result with minimal marketing costs. In this study, further development of scientific and methodological approaches to determining the state of marketing management of the activities of agricultural enterprises of Ukraine under the conditions of international diversification, consisting in the identification of problematic issues arising in the course of international business diversification; quantitative and qualitative assessment and determination of the degree of diversification of the enterprise in different markets, as well as conducting market research of the most important business segments of consumers in foreign markets and selecting the optimal exit strategy of a diversified international markets.
\end{abstract}

Keywords: marketing management, concept of marketing management, international diversification, effectiveness of marketing management, planning, organization and control of enterprise marketing management, evaluation of the degree of diversification of activities, diversified company

\section{Introduction}

There is an opinion that business diversification should not become a strategic priority until the opportunity to grow the company in its main market begins to decline. And this is the only prerequisite for the entry of goods into new markets. That is, for businesses that are successfully operating in the market, diversifying the business of the enterprise is not a defining strategic direction. This is due to the fact that there are many examples where companies that concentrate their business in one market (one country) can make significant gains over the decades without resorting to international business diversification to support their growth.

\footnotetext{
${ }^{1}$ Doctor of Economics Sciences, Professor of the Department of Marketing and Advertising, Vinnytsia Trade and Economics Institute, KNUTE, Ukraine

2Ph.D. in Economics, Associate Professor of the Marketing and Advertising Department, Vinnytsia Trade and Economics Institute, KNUTE, Ukraine

${ }^{3}$ Doctor of Economics Sciences, Professor, Professor of the Department of Marketing, Khmelnytsky National University, Khmelnytsky, Ukraine

${ }^{4}$ Doctor of Economics Siennces, Professor, Head of the Department of Entrepreneurship and Marketing Ivano-Frankivsk National Technical University of Oil and Gas, Ukraine

${ }^{5}$ Ph.D., Associate Professor, International Economic Relations Department, Khmelnytskyi National University, Khmelnytskyi, Ukraine
} 
In today's economic conditions, more and more companies are operating under the conditions of international diversification in order to avoid full financial dependence on the peculiarities of the cyclical development of the domestic market, but also consider the diversification of the enterprise business as a strategy of its development, that is, as a stage in the development of the most successfully functioning enterprise at the moment. In our opinion, under the current conditions, when the socio-economic situation is changing rapidly, one cannot live today and wait for the company's growth opportunities to decline in its main market. It is necessary to anticipate this situation in advance and take counter measures. Therefore, an important issue for any business enterprise in countries with market conditions is the effectiveness of marketing activity management.

\section{Literature Review}

F. Kotler examines marketing management as the art and science of choosing target markets, attracting, retaining and developing customers by creating, delivering and promoting values that are important to them [1, p. 25]. It follows that the main task of marketing management under the conditions of business diversification is to choose the optimal strategy for the company to enter new markets and adequate means of strategy implementation.

Studying the prospects for the development of marketing management in domestic marketing science, A. Voychak in his scientific works gives an idea of the process of marketing management of the domestic enterprises activities, which does not restrict the activity of the enterprise only in the domestic market. The stages of the process of marketing management activities in terms of international diversification are presented in Fig. 1 [2, p. 52].

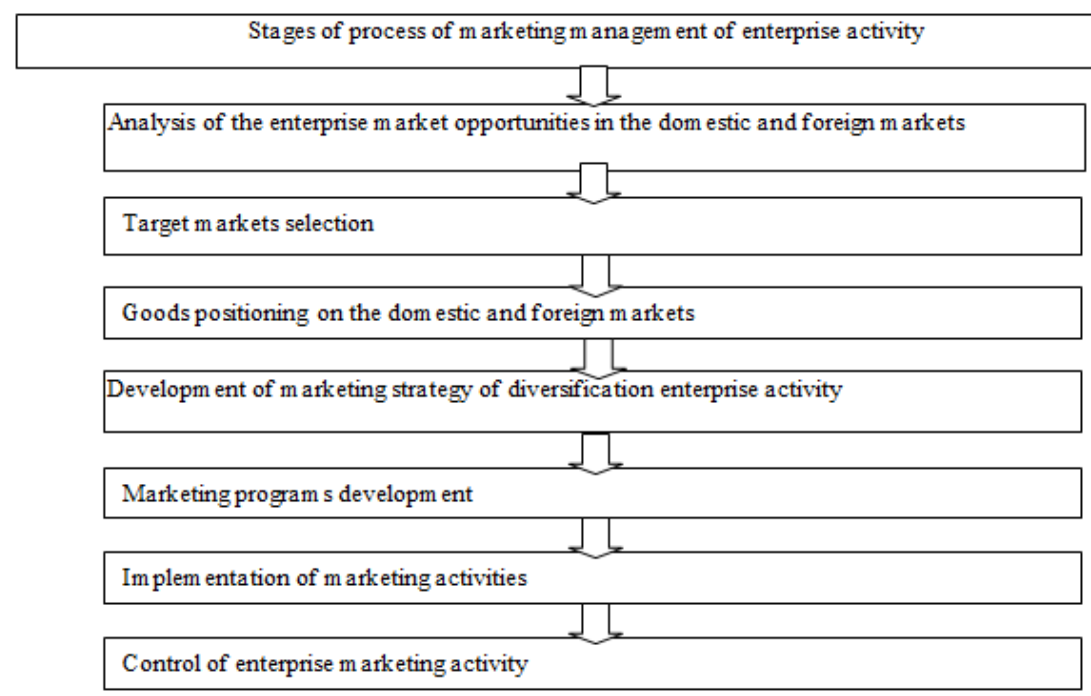

Fig. 1. Stages of process of marketing management of enterprise activity under the conditions of international diversification

Source: $[2$, p. 52$]$ 
Marketing management of business activities in the context of international diversification involves the construction of an appropriate system of information gathering, study of foreign markets, planning, implementation and control of the marketing program, risk and profit assessment, effectiveness of marketing decisions, development of marketing strategy for the activity of the enterprise, which allows to obtain the maximum effect with minimum marketing costs.

This approach to structuring the process of marketing management of business activities in the context of international diversification is quite flexible and allows business entities to determine independently the sequence of stages of entry into a foreign market.

The mechanism of marketing management of enterprise diversification is based on a certain methodology as a set of management principles and methods, providing socioeconomic effect through the formation and implementation of diversification [2, p. 52].

The methodology includes knowledge of the phenomenon and the process of its formation, structured relationships, directions of development, principles of formation (implementation), methods of study and impact. Nowadays, the theory is focused primarily on the development of practical recommendations, and practical problems are solved with the use of theoretical propositions, which are developed in the form of diagrams with application relations to prove their conceptuality. The process of diversification, as an object, necessitates a systematic approach to its study, which determines the methodology for managing it. This takes into account the principles, classifications and methods of analysis used in the complex to ensure continuity in the analytical evaluation of the state of the object. This allows for the implementation of descriptive, explanatory and predictive functions of scientific research. The entity as a hierarchical structure, operating within its subsystems, carries out its own activity in the external environment [2, p. 52].

At the same time, J. Lamben determines that the environment has an influence on the entity in the process of attracting and using resources [3, p. 313]. The process of business diversification of an enterprise from a systematic point of view reveals the properties of complex dynamic systems of the internal and external environment in terms of structural and functional diversity of elements.

In order to better understand and define the concept of marketing management of the enterprise activity, we point out the scientific views of A. Akimtsev and E. Eremin, who clarify the essence of the concept of diversification of enterprise activity, determine the concept of the process of marketing management of enterprise activity in the context of international diversification (Fig. 2) [4, p. 15, 5, p. 18]. 


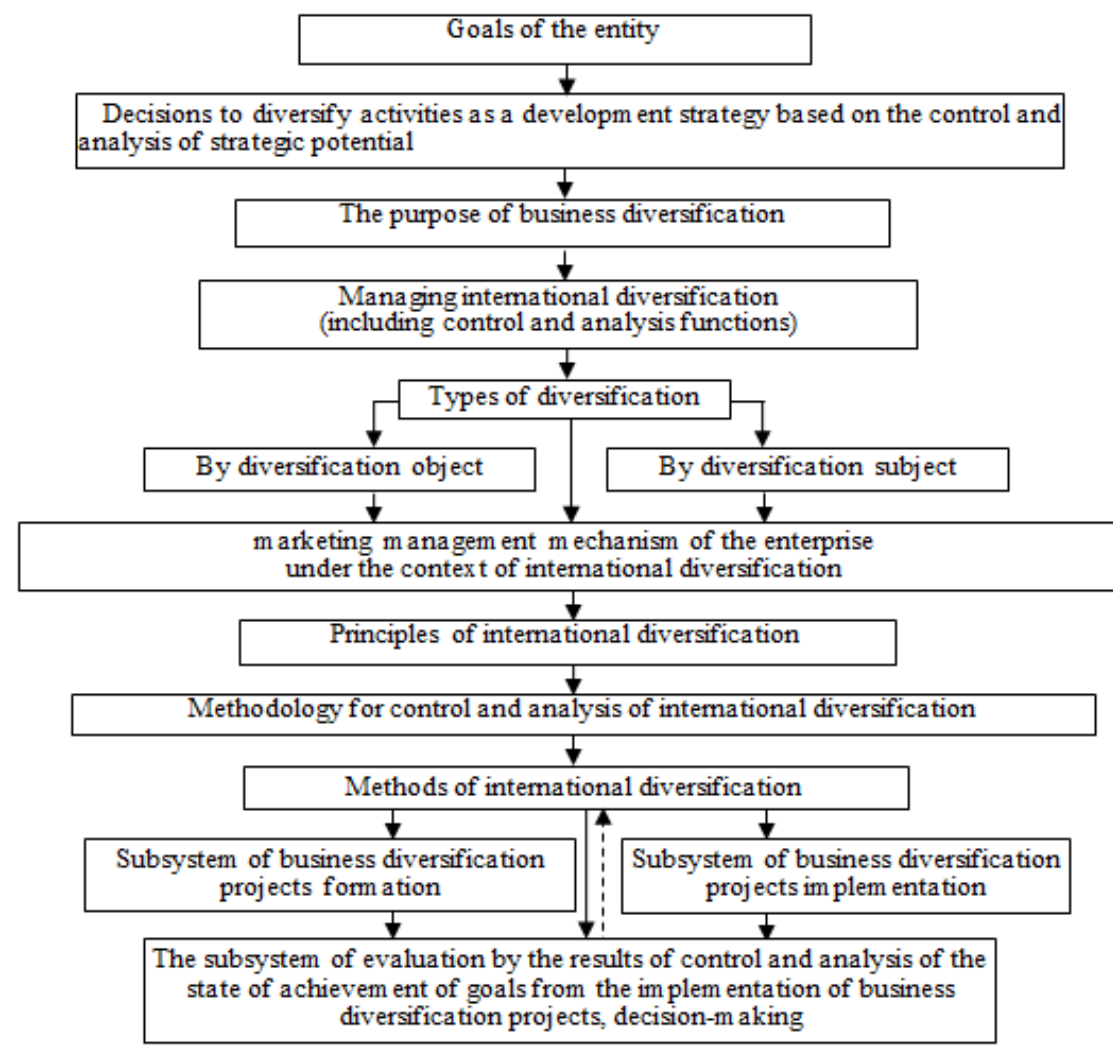

Fig. 2. The concept of marketing management of the enterprise under the conditions of international diversification Source: $[4, p .15,5, p .18]$

The sequence of implementation of the concept of marketing management of the enterprise under the conditions of international diversification contains the following stages [4, p. 15, 5, p. 18]:

1) establishing the goals of the system (corporation, city, region) in which the entity operates through the use of economic relations, including industrial-technical and socioeconomic links;

2) search and formulation of the company's goals in the process of diversification;

3) development of ways to adapt management to these goals;

4) specification of means of achieving the goals.

The main purpose of the process of marketing management of the enterprise in the conditions of international diversification, as an object of control and analysis is to support and coordinate the processes of planning, accounting, control and analysis to determine the status of project implementation and the need for regulation and information support of these processes [4, p. 15, 5, p. 18].

The algorithm of providing these processes with information, according to the stages, is proposed by the scientist-economist V. Semenyuk, defining that the processes of planning, control, analysis and regulation of business diversification of the enterprise form a closed cycle (Fig. 3) [6, p. 135]. 


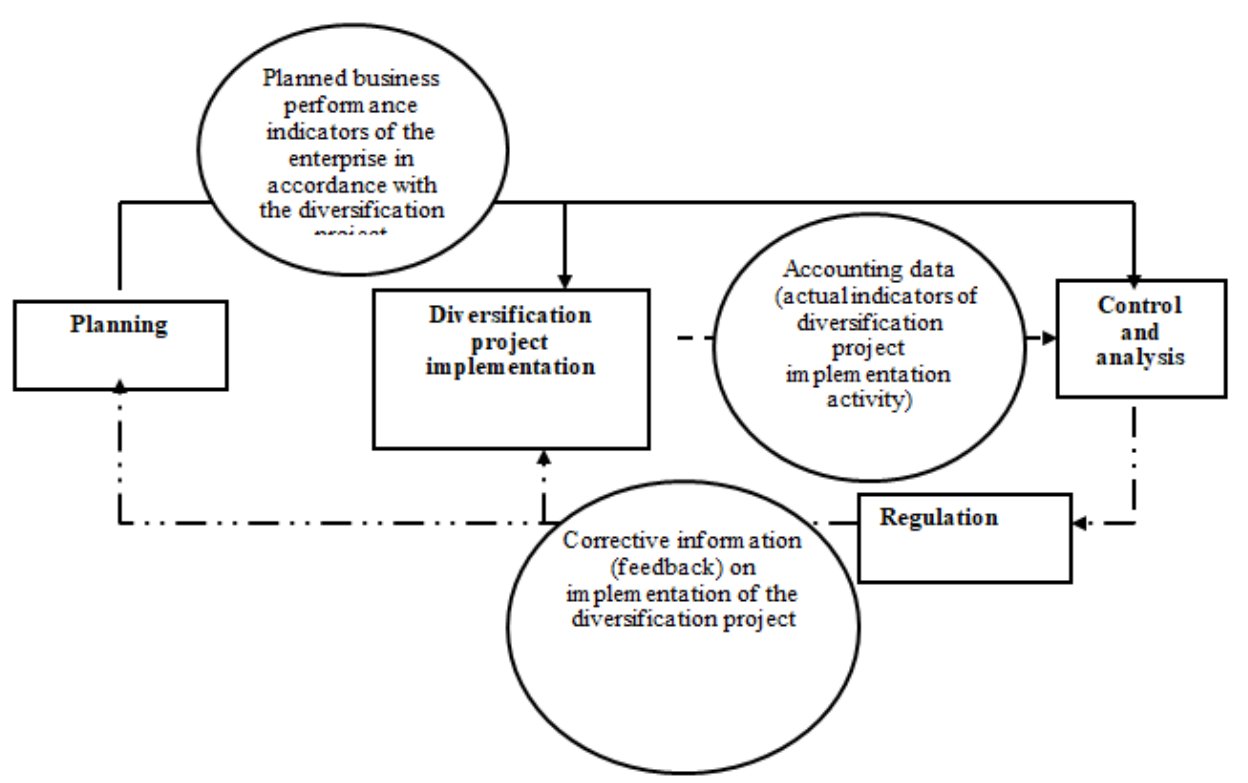

Fig. 3. Block diagram of providing information on the process of marketing management of the enterprise in the conditions of diversification

Source: $[6, p .55]$

Finally, it should be noted that J.-J. Lamben approaches to the construction of a comprehensive system of marketing management of enterprises under the conditions of international diversification are real, since they are aimed at solving the problems of coordination of planning and control activities of the enterprise [3, p. 313]:

- Priority of strategic planning over strategic, with insufficient structure and intensity;

- insufficient detail of plans regarding defined goals and planned activities;

- there is no comprehensive approach to planning and control systems;

- irregularities in the control and adjustment of plans according to changes in the environment;

- formation of planning information base is not ensured, subjective assessments are allowed; shortcomings in ensuring the objectivity of the formation of plans due to the lack of knowledge of the line managers [3, p. 313].

E. Egorov, defining the diversification of the company's activity as a factor of adaptation in the transformative economy, believes that planning the marketing activity of the company in terms of diversification can be strategic, designed for the long term development of the company, and operational, designed to address the short-term objectives of the company, for example, during the year [7, p. 60].

In our opinion, planning as a stage of marketing management of an enterprise in the conditions of diversification, based on systematic analysis, forecasting market trends, estimation of resources, funds needed to implement the planned sequence of actions, marketing measures.

Summarizing the scientific views of the foreign scientist Peter R. Dickson, we can determine that marketing plans play an important role in planning the activities of the 
enterprise in terms of diversification, which can be organized using different approaches. One such approach is the so-called "ring" principle [8, p. 77].

In order to better understand the organization of the process of marketing activity on the "ring" principle, we consider its main stages and their characteristics (Fig. 4) [8, p. 77].

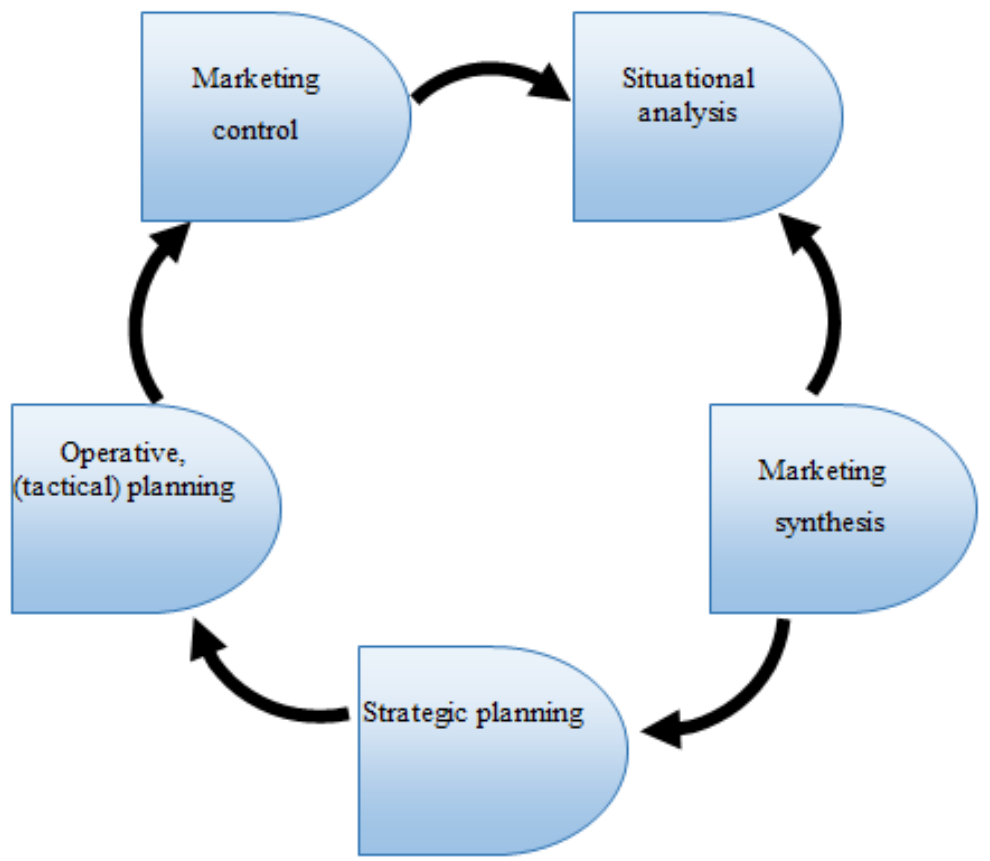

Fig. 4. Organization of marketing activities of the enterprise in terms of diversification on a "ring" principle Source: Developed by the author on the basis of $[8, p .77]$

At the stage of situational analysis, the state of the company, the influence of the external environment, analysis and forecasting of possible situations, events, factors that influence the evolution of the company, its commercial and marketing activities in terms of diversification are evaluated.

Marketing synthesis involves defining and evaluating goals and making strategic planning decisions. Strategic planning is the choice of strategies: which strategy is best and why, how to act to implement this strategy and achieve the goals. During the operational planning, an operational plan of action is developed for the implementation of the marketing program for a year, and then this operational plan, built on the basis of strategic planning, is implemented in practice while conducting the current commercial and marketing activities of the company in terms of diversification. During marketing control, the collection and evaluation of the raw data, which allow you to make decisions about the need for situational analysis [8, p. 77].

During characterizing all stages of the marketing process on a "ring" principle, Peter R. Dickson believes that the basis of planning and control of marketing activities of the enterprise and the conditions of diversification on a "ring" principle is the same basic sequence of actions, the scheme of "feedback" ", Which is used in the organization of 
marketing activities of the enterprise in terms of diversification on the" ring "principle (Fig. 5).

Therefore, this approach, applied at different levels: at the management level of the company and the organization of marketing activity in general and at the operational level - the levels of planning and control of the marketing activity of the enterprise in terms of diversification, allows to organize effectively marketing activities of the enterprise under the conditions of diversification.

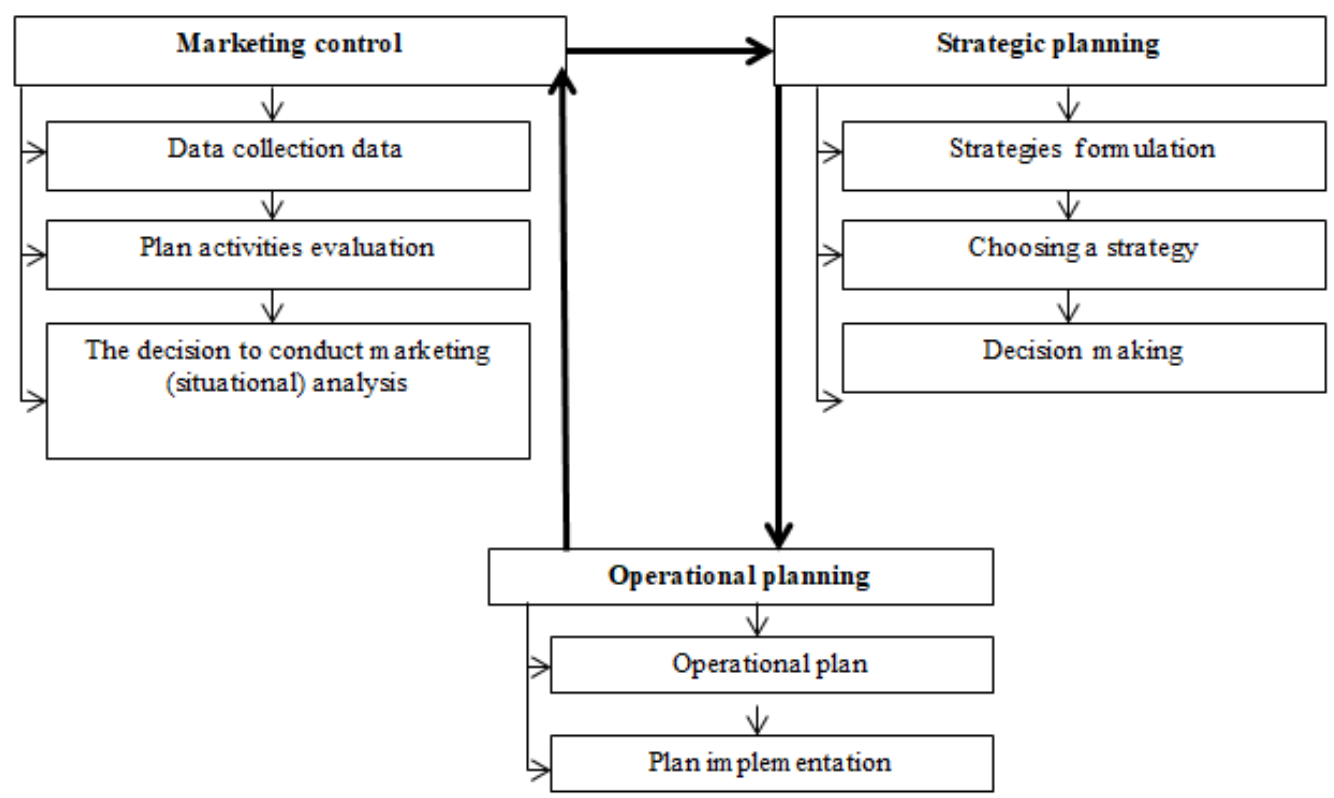

Fig. 5. Planning and control of the enterprise marketing activity under the conditions of diversification on the "ring" principle

Source: Developed by the author on the basis of $[8, p .77]$

\section{Methodology}

In the economic literature, the phenomenon "business diversification" is considered mainly in a foreign enterprise, as it is a relatively new phenomenon for Ukraine. Therefore, in formulating the methodological principles and listing the ways of organizing the system of marketing management of the activity of the enterprise in terms of diversification, we will also refer to the experience of foreign companies, taking into consideration the specificity of domestic enterprises and the current economic situation $[9$, p. 72].

Since the goal of marketing management of an international company is to increase shareholder value rather than to maximize current profits, the situation is that the faster the profits in the company, the higher the price of its shares. Most companies in the West have a complex structure: they consist of several divisions that produce different products and operate in markets in different countries of the world, often unrelated. A. Meyer, determines that if the profits of one unit will increase by $15 \%$ per year and the 
other - by only $2 \%$, then the company should get rid of the slowly growing unit. Sometimes it is the opposite: in order to increase shareholder value, a fast-growing unit is distinguished [10, p. 174].

In the meantime, due to increased competition, Western businesses are focusing on markets where they have competitive advantages and get rid of operations in other distribution markets. For best results, the company needs to strike a balance between cutting off excess units and acquiring new ones that help increase shareholder value.

Based on the mentioned above problems, which arise in the enterprises operating in the markets of different countries of the world, it is worth while noting that the creation of a conglomerate is one of the ways of reducing the dependence of business on the economic cycle. But the conglomerate should consist of enterprises in such industries that are experiencing a cyclical peak in profits at different stages of the economic cycle. Thus, companies that are diversified in such a way that have benefits at all stages of the economic cycle and do not experience recession problems maximize their profits regardless of economic conditions. That is, an enterprise properly organized its business if it operates in different foreign markets and in different industries, since the peak of income in each market (each of the industries) falls at different economic cycle stages. [10, p. 174].

Based on the domestic and foreign sources analysis, which describe specific examples of business diversification of the enterprise and provide an analysis of their consequences, we formulate a set of methodological principles that should be used by domestic enterprises in terms of business diversification, choosing the optimal strategy for entering foreign markets. This complex consists of three groups of principles (Fig. 6).

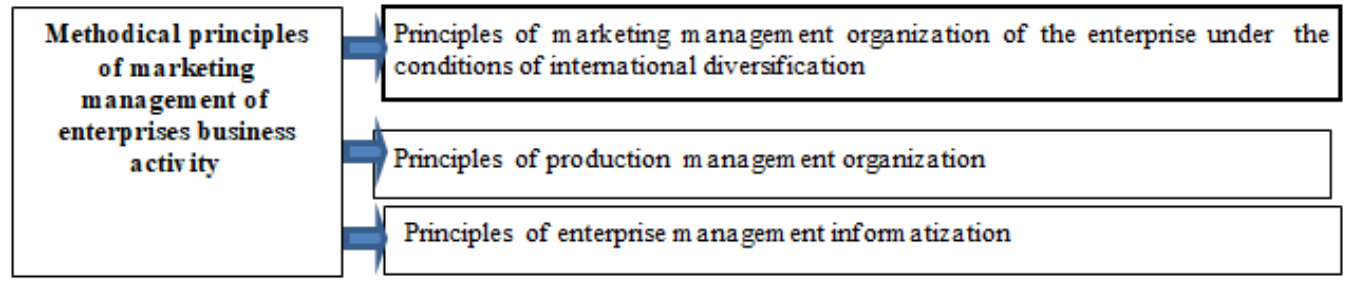

Fig.6. Complex methodical principles of marketing management of enterprise activity under the conditions of international diversification

Source: Developed by the author on the basis of $[5, p .15]$

Consider the characteristics of the first group of principles - "Principles of organization of marketing management of the enterprise under the conditions of international diversification" (Table 1) [5, p. 15]. Based on the principles of organization of marketing management of an enterprise in the context of international diversification, we can conclude that the ability to plan and control the marketing activities of the enterprise in the context of international diversification, the corresponding income and expenses is a prerequisite for the success of the activity. 
Chart 1 - Principles of organization of marketing management of the enterprise under the conditions of international diversification

\begin{tabular}{|c|c|}
\hline Principles & Characteristic \\
\hline $\begin{array}{l}\text { Correcting the tasks of the company } \\
\text { and changing their priorities }\end{array}$ & $\begin{array}{l}\text { Tasks are formed taking into account the state of internal } \\
\text { and external marketing environment }\end{array}$ \\
\hline Effort concentration & $\begin{array}{l}\text { Restriction of the main areas of activity to three to four, } \\
\text { concentration of efforts in more attractive foreign } \\
\text { markets }\end{array}$ \\
\hline Savings and rational use of resources & Focusing on foreign markets with low exit costs \\
\hline Strengthening leadership & $\begin{array}{l}\text { Increasing efforts mainly in those markets where the firm } \\
\text { has a strong position compared to its competitors }\end{array}$ \\
\hline Minimize effort & $\begin{array}{l}\text { Market penetration through new businesses acquisition, } \\
\text { which is more profitable than entering new markets }\end{array}$ \\
\hline High technological production & $\begin{array}{l}\text { Lack of productions with intensive use of human } \\
\text { resources }\end{array}$ \\
\hline The principle of cutting off excess & It is realized through the sale of unprofitable units \\
\hline $\begin{array}{lcr}\text { Improvement } & \text { of organizational and } \\
\text { economic } & \text { independence } & \text { of } \\
\text { enterprise } & \text { subdivisions } & \text { under } \\
\text { conditions of diversification } & \end{array}$ & $\begin{array}{l}\text { Reduction of management centralization (limitation of } \\
\text { control over the spheres of finance, accounting, } \\
\text { planning, law, strategy of purchase of enterprises) and } \\
\text { accordingly granting autonomy to separate divisions }\end{array}$ \\
\hline $\begin{array}{l}\text { Centralization of control of strategic } \\
\text { tasks of the enterprise }\end{array}$ & $\begin{array}{l}\text { In certain situations, it involves controlling the } \\
\text { distribution and use of capital so that responsible branch } \\
\text { managers are unable to use the firm's assets to their } \\
\text { advantage. }\end{array}$ \\
\hline Personal motivation & $\begin{array}{l}\text { It is implemented in the form of encouragement of } \\
\text { executives in accordance with the achieved successes }\end{array}$ \\
\hline Enterprise security & $\begin{array}{l}\text { The need to ensure the security of the company comes } \\
\text { first in the importance of tasks }\end{array}$ \\
\hline
\end{tabular}

Source: Developed by the author on the basis of $[5, p .15]$

In our opinion, such stages as planning and control should be given maximum attention, since the effectiveness of marketing activities of the enterprise in terms of diversification depends on the control over the implementation of marketing annual plans, profitability control and strategic control of activity.

Representatives of the Ukrainian School of Marketing A. Voychak, S. Kovalchuk, A. Pavlenko, A. Savoschenko, A. Fedorchenko point out that control over the implementation of marketing annual plans is an observation of the implementation of specific actions on the marketing plan, control of the implementation of marketing activities, provides analysis and control of certain parameters that characterize the activities to achieve marketing annual plans, such as comparison of planned and actual sales, analysis of the company's share in domestic and foreign markets. These figures are calculated and analyzed on a regular basis, usually on a monthly basis, quarterly. The overall results for the year are summarized at the end of the financial year. [1, 11-20]. E. Novitsky believes that the object of controlling the marketing activity of an enterprise in the context of international diversification is the issues that arise when ensuring the achievement of certain diversification goals; indicators (their deviations) characterizing the state of achievement of the results of the enterprise activity under the conditions of 
international diversification; models and planning methods that ensure the validity of the state for certain periods of time [9, p. 72].

We agree with the opinion of E. Novitsky, that is an important step in controlling the profitability of an enterprise in terms of diversification, which involves control over the budget of marketing programs, projects, calculations of all costs for marketing activities, comparison of these costs with the profit of the enterprise, sales, other economic calculations necessary for the adoption of annual marketing plan and strategic decisions in the marketing activity of the enterprise. It should be noted that profitability control also involves evaluating the profitability of goods, analyzing the assortment of goods, the profitability of the company's activities in market segments, distribution channels. And by determining the ratio between the sales volume of the company in the domestic and foreign markets and marketing costs, we determine the effectiveness of marketing activities of the company in terms of diversification.

The logical step in marketing management of the marketing activity of the company in terms of diversification is the analysis of marketing costs, the complexity of which is determined by R. Nozdrev, highlighting the stages of its conduct [21, p. 207]:

- comparison of sales proceeds, profits of an enterprise with its current expenses and expenses on the basis of accounting reporting, financial statements;

-cost allocation associated with conducting marketing activities of the enterprise in terms of diversification and their distribution by separate items of costs, such as costs for marketing studies of international markets, international advertising, participation in international marketing events (specialized exhibitions), salaries of marketing department employees etc;

- distribution of marketing costs by product or individual product groups, distribution channels, market segments, consumers.

We agree with R. Nozdrev's opinion on the need to allocate costs associated with conducting marketing activities of the enterprise in terms of diversification, but we believe that the budget of marketing programs is planned on the basis of the expected costs of marketing activities and, as a rule, is allocated based on financial opportunities enterprise, current and projected sales, profits of the enterprise.

A. Meyer, V. Mikhailov, A. Pruckov, A. Tyazhov in the scientific works related to the problems of marketing diversification, determine that strategic control of the activity of the enterprise in terms of diversification implies control over the implementation of strategic decisions, control of the budget, control of the effectiveness of marketing management of enterprise activity under the conditions of diversification [10, p. 174].

In agreement with the scientists' opinion, we want to emphasize that the control over the budget foreseen for the implementation of marketing programs is an integral part of financial control over marketing activities in the context of diversification.

At the same time, F. Kotler believes that control of the marketing activity of the company in terms of diversification allows to identify positive and negative moments in the competitive capabilities of the enterprise and provides for the following actions, after which it is possible to make appropriate adjustments in marketing programs and plans of activity [22, p. . 113]:

- analysis of the implementation of the profit plan;

- analysis of the share held by the company in the domestic and foreign markets; 
- analysis of the profitability of sales of goods in the segments of domestic and foreign markets;

- control of the ratio between sales volume and marketing costs;

- analysis of the effectiveness of measures for the promotion of goods to domestic and foreign markets;

- control over the level of advertising expenses [22, p. 113].

Summarizing different scientists' results of research, in our scientific work we come to the conclusion that planning and control of the marketing activity of the enterprise in terms of diversification is one of the main areas of management activity, because it provides long-term development of the company, control of income and marketing expenses of the enterprise, successful implementation of the marketing program of the enterprise.

It follows that the effectiveness of the process of marketing management of enterprises in the international diversification should be determined by indicators that characterize the state of achievement of business diversification results and calculated on the results of control and analysis of the achievement of goals from the implementation of business diversification projects, management decisions.

\section{Results of the Study}

Taking into account the scientific views of economists T. Gaydaenko, N. Pashkusa, who argue that the ability to evaluate marketing management of an enterprise in terms of diversification facilitates economic analysis of the enterprise strategy and its correction, we propose to compare diversification phenomena at the enterprise level, markets. Considering that diversification occurs in several forms (horizontal, vertical, lateral), we consider that it complicates the task of calculating a comparative indicator for a given process, which occurs in different variants. In the studies of foreign economists, several indicators have been developed and the methodology of their calculations is presented [23, p. 407, 24, p. 70].

In the national economic science a great contribution to the systematization of economic and statistical indicators of business diversification was made by N.Safronov and G.Pogosyan. In their works, quantitative indicators of business diversification are divided into 3 groups based on the dimension nature:

- statistical;

- expert;

- a method based on the use of models [25, p. 15, 26, p. 345].

Based on the different scientific approaches and views of marketers, we present a generalized description of the methods that have been developed to quantify business diversification.

We consider it worthwhile pointing out, one of the quantitative assessment methods that has been developed on the reverse principle. The calculations were carried out not by the total amount of income received by the enterprise, but by the share in the main market of "main" products. By means of this method is relatively easy to calculate quantitative data. However, in our opinion, it gives an opportunity to obtain an indicator that can more testify to the degree of the company specialization in the traditional markets 
without giving information about the enterprise's expansion breadth into foreign markets. Therefore, the scope of such an indicator is relatively narrow - it is advisable to calculate it for evaluation the diversification of companies business with a with a strong industry affiliation.

The next indicator that from our point of view should be noted is the degree of business diversification, which involves measuring by counting the industries (markets, including foreign ones) in which the enterprise actually operates. This method, at first glance, is extremely simple and understandable. However, there is a downside to this quantitative assessment, since such an assessment does not take into consideration the extent to which a particular business activity in the domestic and foreign markets is developed. If, for example, the share of a firm's transactions in a particular market (industry) is sufficiently low (relative to the total amount of the firm's transactions), then the fact of reflecting this market (industry) in terms of the degree of business diversification (for that firm) will not matter. In our opinion, this indicator does not reflect the level of control of the enterprise over the market. Obviously, in low-capacity markets, the dominant position of the enterprise and a high degree of market reach make it possible to maximize profit "at the rate". Thus, we can conclude that the use of such an indicator is generally incorrect for firms diversified in different domestic and foreign markets.

The proposed methods of quantifying business diversification require adjustment using statistical indexes. The general principle of their calculations is to account the number of markets (industries, business areas) and the relative share that falls on a given market (industry, business sector) in the total volume of business activity of the firm.

The statistical method has been developed in the most detailed form in economic literature of foreign countries. The theoretical substantiation of the application of the most capacious and representative index i.e. the Atton's index was proposed by I. Lisynenko [27, p. 22].

It should be mentioned that the effectiveness of the business diversification strategy depends on the quality of the evaluation. Quantitative assessment of the level of diversification of the domestic enterprises activity has not been developed so far.

In our opinion, statistical methods are the most appropriate to summarize significant amounts of economic information. Up to now, the following indicators are so scientifically substantiated and methodologically developed enough that can be used to describe the processes of the business of production and capital diversification:

- Atton's index,

- Gort's index,

- Berry's index,

- entropy west.

Consider the index developed by the American economist M. Atton in 1979, which suggests the use of the following scheme of calculations (1.1) [27, p. 22]:

$W=\left(\sum_{1}^{r} j * S_{j}\right)-1$

Where $\mathrm{S} j$ - denotes the share of business operations of the enterprise in the $j$-th market, $r$ - number of markets (industries) in which the enterprise operates.

Atton's index can be from 1 (for an enterprise that operates only in one market (in one industry)) to $r$ (if the enterprise evenly distributes its activity between the domestic and 
foreign markets (all industries in which it operates)).

We believe that this indicator should be recognized as the most adequate assessment of the effectiveness of the process of marketing management of the enterprise activity in the context of international diversification, although its value may also distort real significance for the enterprise in domestic or foreign markets, since the Atton's index is highly dependent on the price ratio for goods (services), implemented by the company in different markets.

Therefore, the Atton's index should be used in the analysis of the factor of globalization of diversified development. The cost of goods and services produced and sold by an enterprise in different countries is significantly influenced by two factors [27, p. 22]:

- the nominal one, real and exchange rates and the deviation of their purchasing power parity,

- state protectionist policy, especially its tariff forms (taxes, duties, payments).

From our point of view, it is of fundamental importance to ensure the correctness and consistency of the calculations, which should be considered as a restatement of the currency turnover of the enterprise on the purchasing power parity and the exclusion from the calculation of indirect taxes and duties.

In developing quantitative methods of analysis, M. Gort drew one's attention to the fact that the quantitative approach involves either calculating the absolute number of markets covered (goods, industries, regions), or determining their relative shares (relative values), reflecting the importance of each domestic or foreign market in to which the enterprise operates [27, p. 22].

However, the application of this method has some problems, and Gort attributed the following:

- the problem of finding boundaries between different market segments;

- the indicator of the number of different markets used by the firm does not give an idea of the importance of each of them for the total turnover and income of the enterprise; - number of markets is not a sign of technological or marketing dependence, which does not allow to directly distinguish between business diversification and differentiation of goods or services.

A simple (mechanical) calculation of the markets can lead to the fact that the degree of diversification of the business of the enterprise will prove too high. To eliminate this deficiency,

M. Gort introduced into the scientific circulation 7 indices, the purpose of which was to generalize the various parameters of the phenomenon under consideration. With their help, it was suggested to evaluate the importance of different markets for an enterprise engaged in diversification activities (in the form, for example, of indicators such as "most significant", "less significant", etc.) [27, p. 22].

The Gort's index method has some advantages over the conventional quantitative approach, as it indicates the relative importance of different market segments. In general, it can be noted that Atton's and Gort's application methods allows estimating the degree of international business diversification.

Therefore, this index can overstate the degree of diversification (as is sometimes the case with the simple method of number of foreign markets calculating). This remark is relevant if the company is involved in several different but comparable in size 
international markets.

Another indicator of the degree of business diversification developed by American economist $\mathrm{K}$. Berry is also being actively used. This indicator allows taking into account the relative shares of turnover of all types of the firm activity. Berry's Business Diversification Index is determined by the following formula [27, p. 22]:

$$
D_{B}=1-\sum_{1}^{n} P_{i}^{2}
$$

where Db - Berry - Business Diversification Index;

$\mathrm{n}$ - number of business units in different markets;

$\mathrm{Pi}$ is the relative turnover that is made on the market $\mathrm{i}(1<$ and $<\mathrm{n})$.

Obviously, the range of change of the Berry's index is normalized and is within $0<\mathrm{Db}$ $<1$. Hence, the Berry Index scores zero when a company specializes in only one market. The greater the degree of business diversification, the more the index approaches to 1 .

Like the previous indicator, the Berry's Index can be applied to both territorial (geographical) and functional business diversification. The modification of this indicator allows obtaining a mixed Dbg index, by means of which one may account for both production and territorial business diversification. Its mathematical formula:

$$
D_{B G}=\sqrt{\sum_{r=1}^{n} P_{i}^{2} \sum_{j=1}^{m} r_{j}^{2}},
$$

where Dbg is the Berry's integral index of productive (functional) and territorial (geographical) business diversification;

$\mathrm{r}$ - market share (segment) J.

Another element, the so-called equivalent figure, can be added to the Berry's index, which gives information on what markets other businesses, similar in degree of business diversification, might be showing. This modified Berry - Index was called "Numbers Equivalent". This indicator (NE) is calculated by the formula [27, p. 22]:

$$
N E_{i}=\frac{1}{\sum_{i=1}^{n} P_{t}}=\frac{1}{1-D_{B}}
$$

In addition to these indexes, in the research of market opportunities of an enterprise in the domestic and foreign markets another indicator is used, which is called "measure of entropy" (uncertainty). This indicator of the business diversification degree was proposed by two researchers: A. Jacquemin and K. Berry [28, p. 359].

The measure of entropy (E) is (like the Berry's index) the sum of the weighted average parts of turnover of all spheres of business activity of the firm. These values are determined (unlike the Berry's index) by the natural logarithm of the inverse turnover in a particular market. The indicator is determined by the following formula

$$
: E=\sum_{i=1}^{n} P_{i} * \ln 1 / P_{i}
$$

where $\mathrm{E}$ is the entropy measure of the enterprise diversification,

$\mathrm{n}$ - the number of different markets for the sale of the company,

$\mathrm{p}$ - relative turnover in the market.

The degree of diversification of activity of one enterprise consists, according to the methodology of this indicator, of two components. [29, c. 215]: 
- the degree of activities diversification in one market (which characterizes the related diversification of activities),

- the degree of activities diversification in different markets (unrelated activities diversification).

The first component (measuring the activities diversification within a single market) differs from the Berry's index by a more sensitive measure. Economists' studies (in particular, E. Hoskisson) have shown that the measure of "entropy" accurately reflects the actual degree of diversification of activity, that is, dispersion of business activity in different markets [30, p. 215].

Having considered the methods of analysis of quantitative aspects of diversification of activities, we turn to methods by which it is possible to evaluate the qualitative parameters of this process. Such measurement methods include the so-called categorical method.

Qualitative indicators of diversification of activity give an idea of the specifics of the choice of the enterprise "product-market" [29, p. 399]. This method involves the use of "inside" information that reflects the strategic plans of the enterprise. In this regard, its use is only possible at the intrinsic level of the company for the purpose of marketing management of the enterprise in diversification conditions.

This method of measuring the diversification activities was proposed by the American economists L. Ringley and R. Rumelt [31, p. 557]. According to their concept, diversification of the enterprise activity can be determined by type and volume. In order to measure the scale of enterprise activity diversification, it was proposed to use 4 types of categories:

Simple product;

dominant product;

Related Product;

Unrelated Product.

The basis of such stratification was the indicator of specialization (the so-called "measure of specialization", SR), which is defined as the ratio of turnover of the largest volume in the market to the turnover of the firm in all markets. As has been mentioned earlier, there is a distinction between related and unrelated diversification of activities.

According to L. Ringley's approach, the category "simple product" refers to all enterprises in which the total volume of manufactured products at least $95 \%$ consists of one product. If this figure is $70-95 \%$, then it is a "dominant product". As for companies where the share of one product is below $70 \%$, two options are indicated [31, p. 557]. The "related product" category is related to those businesses in which all elements of the production program are related. In this case, we can talk about the interdependence in the field of technology or market process. In other cases, it is customary to use the concept of "unrelated product".

L. Ringley's concept was refined by P. Rumelt. He proposed three indicators for the enterprises classification [31, p. 558]:

- degree (extent) of specialization,

- the degree of affinity, characterized by the ratio of turnover of related industrial spheres of the enterprise to the total turnover,

- the degree of vertical linkage that determines the proportion of turnover of vertically 
related activities of the firm in the total turnover of the firm.

According to the first indicator (degree of specialization), enterprises differ in the same way as reflected in L. Ringley's classification. However, P. Rumelt uses in his scheme not the number of different products, but the so-called "discrete business" [31, p. 559]. This concept means those areas of activity that are independent of each other. Independence is manifested when the business unit can be separated from the enterprise and this will not affect the activities of its other units. That is, P. Rumelt's theory must be applied to enterprises operating in the context of international diversification, namely that diversification is perceived as a prerequisite for entering new sales markets.

Indicator "Degree of vertical connection"is used to separate vertically integrated enterprises from enterprises that do not have such integration. When the figure is higher than 0.7 , the enterprise should be considered vertically integrated. A general overview of the classification used by P. Rumelt can be clearly illustrated as a structural and logical scheme (Fig. 7) [31, p. 557].

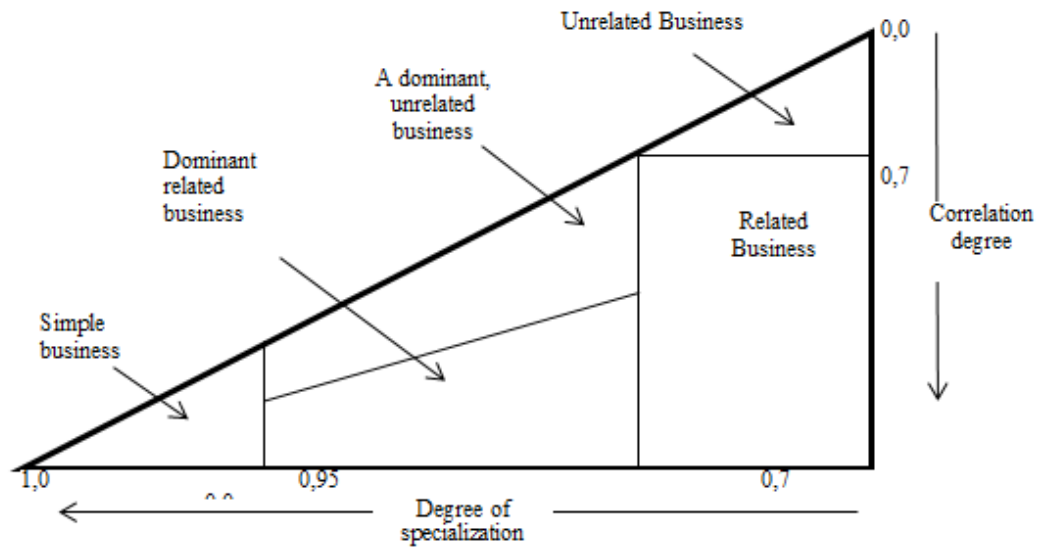

Fig. 7. Discrete-categorical evaluation of activity diversification

Source: [31, p. 557]

The proposed methods, indicators for assessing the degree of diversification of enterprises can be used in assessing the effectiveness of marketing management of the enterprise in international diversification, but it is advisable to mention that there is a linear dependence of this process on the systematic approach to the implementation of the project diversification of activities.

In order to further develop a methodology for evaluating the effectiveness of marketing management of an enterprise in the context of international diversification, the main priorities of which are entering new markets, we propose to take into consideration the following factors:

- risk-return ratio;

- the purpose of business development, the main industries in which the activity, specialization and image of the organization is carried out;

- requirements for the size and adequacy of equity (when entering international markets, the standards of other countries where it is intended to do business should be taken into 
account);

- legislative and regulatory framework;

- competition in national and international markets;

- macroeconomic parameters and conditions;

- marketing research of the most important business consumers' segments of foreign markets.

In modern conditions of management, domestic enterprises must consider the methodological principles and methods of the management system organizing of the most promising areas of activity. Based on the stages of the process of marketing management of an enterprise in the context of international diversification, taking into consideration the factors that must be paid attention to when evaluating its effectiveness, we propose to identify and form zones of potential product distribution and determine the competitive environment impact on the enterprise in the international diversification. It is obvious that the identification of potential distribution zones of products in the context of international diversification requires consideration of additional factors reflecting the peculiarities of a country. In particular, they are indicators of economic integration proposed to assess the marketing attractiveness of new international markets for the activity of enterprises [21, p. 339].

E. Egorov believes that to characterize the competitive environment, it is necessary to assess the indicators of economic integration, which is determined by the groups, taking into account the legal restrictions in the field of sales in the relevant market [7, p. 60], $[32$, p. 233]:

- a set of country-specific characteristics: manufacturer's price, shipping costs, distributor markup, etc ;

- a group of characteristics peculiar to the international market: customs tariff, currency corridor, quotas, etc. [7, p. 60].

E. Egorov proposes to evaluate the conditions of activity in the new foreign market taking into consideration the influence of market restrictions on the products distribution. Assuming enterprise $A$ is located in country V; and enterprise B is located in country W; moreover, enterprise B, using its available reserves, intends to sell its own production in the territory of state $\mathrm{V}$ (Fig. 8). In this case, the advantage of enterprise B over producer $\mathrm{A}$ in the price ratio can be represented as follows:

$X=C_{B}^{\prime}-C_{A}^{\prime}$

where $C^{\prime} b$ and $C^{\prime} a$ - the total consumer cost to purchase products from either manufacturer $\mathrm{B}$ or its competitor - manufacturer $\mathrm{A}$, and

$$
\begin{aligned}
& C_{A}^{\prime}=C_{A} \div p * t_{A} \\
& C_{B}^{\prime}=C_{B} \div p * t_{B}
\end{aligned}
$$

where $\mathrm{Cb}$ and $\mathrm{Ca}$ - selling prices for products respectively manufacturers $\mathrm{B}$ and $\mathrm{A}$.

Let the political boundary between states $\mathrm{V}$ and $\mathrm{W}$ be represented by line $\mathrm{I}-\mathrm{I}$. In this case, formula (1.8) can be converted as follows

$$
C_{B}^{\prime}=C_{B}+T F * C_{B}+p w * t b w-p v * t b v
$$

where TF is the customs tariff, a percentage of the customs value, or in the ECU; $\varphi \mathrm{pw}$ and $\mathrm{pv}$ are the cost of transportation cargo the territories of $\mathrm{W}$ and $\mathrm{V}$.; 
tbw and tbv - transportation of goods distance by the territories of the countries $\mathrm{W}$ and $\mathrm{V}$.

In most cases, the value of $\mathrm{tWw}$ is determined by customs office location (ex-departure station, ex-wagon, etc.) (Fig. 8) [7, p. 60].

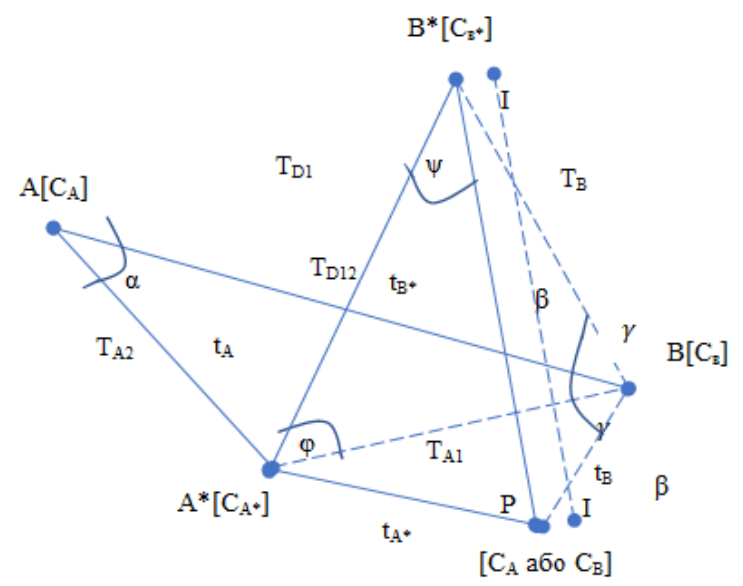

Fig. 8. Scheme of the location of the subjects of market relations under the conditions of international diversification of activity

Source: $[7$, p. 60]

In addition to the customs tariff, the restriction on international diversification may be a currency corridor, in view of which expression (1.9) is transformed into the formula:

$C_{B}^{\prime}=\xi\left(C_{B}+p w * t b w+T F * C_{B}\right)+p v * t b v$

where $\xi$ is the official exchange rate of the countries $\mathrm{V}$ and $\mathrm{W}$.

Returning to expression (1.6) using relations (1.7) and (1.8), we obtain formula (1.11) in which

$$
G=\frac{\xi\left(C_{B}+T F * C_{B}\right)-C_{A} \pm N}{P_{v}}-t_{B W}\left(\xi * \frac{P_{W}}{P_{V}}-1\right)
$$

In addition $t_{B 1}=f(\beta)$.

Similarly alternative options for delimiting zones of potential product distribution can be calculated, for example, between manufacturer B and its distributor B * located in State $\mathrm{V}[7$, p. 60].

In this case

$G=\left(T_{W}-t_{W}\right) *\left(\xi * \frac{P_{W}}{P_{V}}-1\right)-\frac{ \pm X-\delta}{T_{W}}$

In addition $t_{B 1}=f(y)$.

It is obvious that the customs tariff and the official exchange rate can create conditions under which the products export from country $\mathrm{W}$ to country $\mathrm{V}$ may prove economically impractical, even if there are certain advantages reflected by the value of X. Moreover, if appropriate measures are not taken by $\mathrm{W}$ protection of the rights of its own producers, 
favorable conditions may arise for the penetration of the products of producer A into the domestic market of the state $\mathrm{W}$, with the corresponding reduction of potential distribution zone of the products of producer $\mathrm{B}$, as a result, its economic well-being is impaired.

It should be regarded, that two main methods can be used in the construction of delimitation of zones lines, due to the uncertainty of the value of tbw in formulas (1.11) and (1.12), depending on one of the angles - $\beta$ or $\gamma$, respectively.

The first approach is based on the parallel (along with the main) tracking of the dependence of $t_{B W}=f(\beta)$ aбo $t_{B W}=f(\gamma)$ that is, the concomitant determination of distances from the manufacturer's location to the political boundary, depending on angular magnitude. In this case (in particular $t_{B W}=f_{1}(\beta)$ the dependence of the shape of the demarcation line on the configuration of the political boundary is clearly traced.

The second method is based on taking into consideration the finite number customs posts nt, on the border of states $\mathrm{V}$ and $\mathrm{W}$. In this case, depending on $\mathrm{nt}$, nt lines of demarcation are constructed at fixed values in each case tbw, based on the manufacturer's location as if moved to a customs point (departure station, ex-wagon, etc.).

The geographical proximity of rival companies under the conditions of international diversification of the enterprise activity influences the formation of competitive environment, which contributes to the increase of efficiency and specialization of production, improved technological processes and innovations introduction [7, p. 60]. At the same time, an important task is to analyze the effect of the concentration of manufacturers on the efficiency of product distribution, as well as to substantiate the marketing strategy of diversification of the enterprise entering the foreign market in the presence of competitors located in close proximity.

Suppose that the rival companies $\mathrm{A}$ and $\mathrm{B}$ are located in the territory $W_{\Sigma}$ in one settlement (Fig. 9), and prices for products in them are the same.

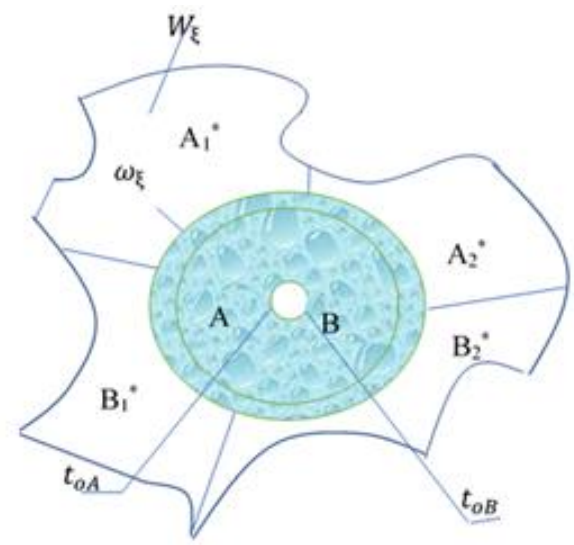

Fig. 9. Scheme of delimitation of zones of potential distribution producers' products under the conditions of international diversification in the competitive market

Source: $[7$, p. 60] 
Otherwise, in the case of price targeting, buyers prefer to buy goods from a low-priced manufacturer. Suppose that within the territory $W_{\Sigma}$ of the preliminary estimates can be sold $\mathrm{N}$ products, and:

$\mathrm{N}=\mathrm{Na}+\mathrm{Nb}(1.13)$

where $\mathrm{Na}=\mathrm{HB}$ - the number of products sold by manufacturers $\mathrm{A}$ and $\mathrm{B}$ respectively, you can determine the scattering indices

$$
\begin{aligned}
& i_{A}=\sqrt{\frac{W_{\xi}}{\pi * N_{A}}} \\
& i_{B}=\sqrt{\frac{W_{\xi}}{\pi * N_{B}}}
\end{aligned}
$$

That is $\mathrm{I}_{\mathrm{A}}=\mathrm{IB}_{\mathrm{B}}=\mathrm{I}_{2}$.

The next step is to determine the optimum radius of the direct sales area. The areas of direct sales of $\mathrm{A}$ and $\mathrm{B}$ producers coincide, so it is not possible to delimit areas of influence within a single zone $\omega^{\prime}$, which undoubtedly has a positive effect on the competition process. In other words, the sales area $\omega^{\prime}$ is a kind of barometer that responds to the advantages of one of its competitors. Obviously, the remaining part of the zone $W_{\Sigma}-\omega^{\prime}$ can be divided between manufacturers $\mathrm{A}$ and $\mathrm{B}$ according to the results of the preliminary agreement (Fig. 10) [7, c. 60].

At this

$W_{A}^{*}=W_{B}^{*}=\frac{W_{\xi}-\omega_{\xi}}{2}$

The areas $W_{A}^{*}$ and $W_{B}^{*}$ are subject to sharing between distributors $A_{1}^{*}, A_{2}^{*}, A_{n}^{*}$ та $B_{1}^{*}, B_{2}^{*}, B_{n}^{*}$. At this should be considered that the optimal radius of the potential distribution area of a distributor's product is not determined by the scattering index In calculated for only one subject of market relations. Therefore, the value of this radius will be smaller than T0.

The dependence of the scattering index ik on the number of competitors concentrated in a given zone is deduced as follows:

$i_{k}=\sqrt{k} * i_{1}$

Suppose that in the future, consumer preferences have changed, started to get an unequal amount of goods of enterprises $\mathrm{A}$ and $\mathrm{B}$. The latter is possible for several reasons: improvement of some technical characteristics, more aggressive advertising, better service and more.

At this expression $\quad N=N_{A}+N_{B}$ : will be in the following form

$N=p * N_{A}+(1-p) * N_{B}$

ae $0 \leq p \leq 1$.

In this case, the sizes of the zones of direct distribution of the producers' products do not coincide. Increasing sales leads to a decrease in the scattering index, for example $i_{B}$ formula (1.15), ib formula (1.15), and at the same time to reduce the optimum radius T0 of the formula $\left.t_{0}=\sqrt[3]{\frac{3 * i^{2} * f}{a}}\right)$. 
The latter circumstance leads to a change in pricing parameters (distributor trade discounts). Reverse patterns are observed for the area of direct distribution of manufacturer's A products. At the same time, there is an outflow of part of the peripheral consumers

from distributors $A_{1}^{*}, A_{2}^{*}, A_{n \text { i t o distributors }}^{*} B_{1}^{*}, B_{2}^{*}, B_{n}^{*}$.

Sales statistics will further assess the feasibility of attracting and selling new reseller products by reaching No (formula $n_{0}=\sqrt[3]{\frac{9 * f^{2}}{a^{*} i^{2}}}$ ).

Must be considered that the potential distribution area of the "new" distributor consists of the residuals of the reduction of the manufacturer's direct distribution area and of the areas taken away from the distributors $A_{1}^{*} A_{2}^{*}$.

The latter circumstance leads to the redistribution of the zones of potential distribution of products, in particular, in the involvement of one of the distributors $A_{1}^{*}$ or $A_{2}^{*}$ manufacturer $\mathrm{A}$.

This situation eventually forces the manufacturers - competitors to use non-price methods of competition.

For the markets of highly developed countries, the emergence of "new" rival companies, such as $\mathrm{E}$ (Figure 10), which causes a "delimitation" of part of the zone ${ }^{W_{\Sigma}}$, is natural, causing "delimitation" of part of the zone - from manufacturers A and B.

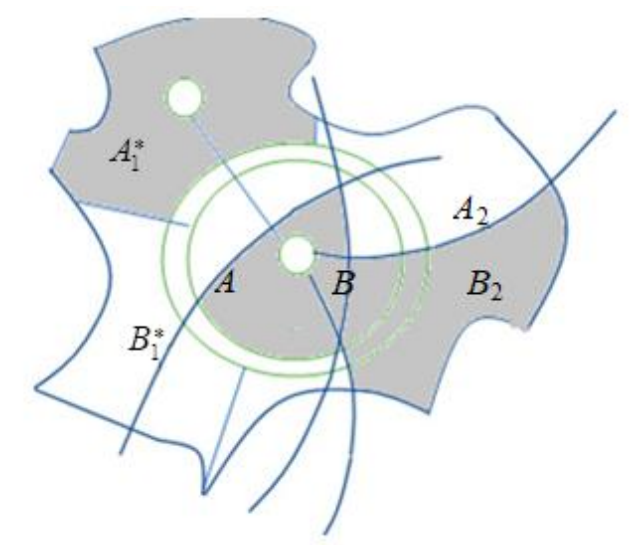

Fig. 10. Scheme of delimitation of zones of influence between manufacturers $A$ and $B$ with the advent of competitor E

Source: $[7$, p. 60]

It is obvious that the location of enterprise $\mathrm{E}$, which does not have a material advantage over its competitors $\mathrm{A}$ and $\mathrm{B}$, may have an ambiguous effect on the distribution possibilities of the latter's products.

In Fig. 10 shows that the location of the rival company at point $\mathrm{E}$ resulted in approximately the same loss to manufacturers $\mathrm{A}$ and $\mathrm{B}$, which could ultimately lead to their joint actions aimed at blocking the activity of a "new" competitor. In circumstances 
where there is no guarantee of effective confrontation, careful consideration should be given to the choice of location of company E. In order to "exclude" one of the competitors without affecting its territorial interests, it is advisable to place a new company $\mathrm{E}$ in the immediate vicinity of one of the distributors., for example, $A_{1}^{*}$ by counting on consumer's savings in transportation costs from manufacturer A to distributor.

This will not only reduce the impact of competition, but also in the case of successful actions to push the reseller out of his area, which is optimal in terms of sales of these products, that is, with the transformation of the latter into a manufacturer's $\mathrm{E}$ zone of direct distribution.

It should be kept in mind that manufacturer B is also interested in displacing competitor A, since this measure will allow him to:

- conquer the interests of the area of direct distribution $\omega$ ';

- further reach the area of potential distribution of distributor's $A_{2}^{*}$ products;

- at price parity with producer $\mathrm{E}$, cover more of the area than the latter.

Evidently, company E may be Manufacturer's B subsidiary interested in a larger share of the market, which should also be taken into account for Company A.

Based on the stages of the process of marketing enterprise activity management in the context of international diversification, taking into consideration all appropriate factors when assessing the effectiveness of marketing management of the diversification company, we offer, after determining the international markets that will become potential for the products division, determining the impact of competitive environment on the enterprise conditions of international diversification, marketing attractiveness assessment of new international markets for business activity to consider a model of penetration of a diversified company into international markets [33, p. 56].

Considering a system of three participants in a diversified company, including a product manufacturer, processing company, commercial service. Let $x 1, y 1$ be the product purchased for the manufacturer and the production volume of the supplier's enterprise, $x 2, y 2$ be the product purchased for the manufacturer and the production volume of the production of the consumer enterprise, where the vector $x 1,=(x 1 i), i=1 \ldots i \times 1 i$ is the quantity of production purchased for the producer of the species $i, y 1=(x 2 j), j=1 \ldots j$; $y 1$ is the volume of production intended for the manufacturer; vector $x 2,=(x 2 j), j=1 \ldots$ $j ; \times 2 j$ is the quantity of production purchased for the manufacturer of the form $j ; y 2=$ $(y 2 k), k=1 \ldots k ; y 2 k$ is the volume of production of the type $\mathrm{k}$ intended for sale at domestic and international markets, the production of which provides the implementation of the marketing program of an international diversified company [33, p. 56].

Suppose that the diversification of supplier and consumer production requires investment in the working assets of everyone in the amount of $f 1$, $f 2$. In a competitive international market and the marketing technologies present in it, you can determine the price of the product, the direct costs of the manufacturer to produce products, the cost of purchasing raw materials, the size of the working capital of the manufacturer: prices $c 2$ $=(c 2 k), k=11, \ldots ., K$ of final products; $p 2=(p 2 k), k=11, \ldots ., K$ - direct costs of the manufacturer for the production of type $\mathrm{k}$ products without taking into account the cost 
of purchasing raw materials; indirect costs of the manufacturer - $q 2$, the size of the working capital of the manufacturer - v2, turnover of working capital for the period of production - 02 , matrix $B$ defines raw material needs, where the element of the matrix $b j k, j=1, \ldots, J, k=1, \ldots, K$, equal to the amount of raw materials of type $j$ required by the manufacturer to produce products of type $k$. For the diversification of production, the manufacturer requires the costs of fixed assets in the amount specified by the value of F2 [33, p. 56].

Consider the indicators of production and economic activity of the supplier of raw materials. Given its direct current costs $p 1=(p 1 j), j=1 l, \ldots, J$, where $p 1$ is the supplier's direct costs for the production of type $j$ products without taking into consideration the cost of purchasing supplies, $q 1$ - the indirect costs of the supplier, $v 2$ - the size of circulating supplier's means, 01 - turnover of these circulating assets for the period of production, matrix A defines the needs of consumables, where the element of the matrix aij $i=1, \ldots, I, j=j, \ldots, J$ equal to the amount of consumables type $i$ required by the supplier for the production of a unit of type j. $s=(s i), i=1, \ldots, i$, - supplier's supply prices, where $s i$ is the price of product type $i$; the supplier produces and sells to the consumer his own final consumption goods at prices specified by the vector $c 1=(c i j)$, cij the price of the supplier's type $j$ final consumption goods. For the diversification of the business to the supplier, it is required expenditures on fixed assets to the extent specified by F1 [33, p. 56].

One of the divisions (participants) of the diversified company (financial and settlement department, economic support unit) invests in the diversification of the supplier and the manufacturer financial resources in the amount of $\mathrm{S}$.

The task is to determine the costs and output of the supplier $(x 1, y 1)$, the costs and output of the manufacturer $\left(x 2, y^{2}\right)$, investments in the working assets of the supplier and manufacturer $(f 1, f 2)$, which will increase their profits:

$$
\pi=c_{1} y_{1}-\left(p_{1} y_{1}+s x_{1}+q_{1}\right)+c_{2} y_{2}-\left(p_{2} y_{2}+c_{1} x_{2}+q_{2}\right)
$$

Revolving means as a result of diversification of the company and investment of additional funds, if necessary, should ensure payment of the running costs of the manufacturer and supplier, and therefore

$$
\begin{aligned}
& \left(p_{1} y_{1}+s x_{1}+q_{1}\right) \leq o_{1}\left(v_{1}+f_{1}\right) \\
& \left(p_{2} y_{2}+c_{1} x_{2}+q_{2}\right) \leq o_{2}\left(v_{2}+f_{2}\right)
\end{aligned}
$$

Restrictions on the amount of funds that the financial and accounting department, economic support unit that agree to invest in the economic activities of the manufacturer and supplier to diversify the company, will look like:

$$
F_{1}+f_{1}+F_{2}+f_{2} \leq S
$$

The volume of consumables of the manufacturer and the supplier necessary for the production of final consumption products is determined by the following conditions:

$$
\begin{aligned}
& x_{1}=A y_{1} \\
& x_{2}=B y_{2}
\end{aligned}
$$

Consider the vendor's production product volume who sells it to the manufacturer, and the manufacturer's expense cost at this volume: 
$Y_{1}=x_{2}$

Considering (1.23) - (1.25) we have $y_{1}=x_{2}=B y_{2}$ i

$x_{1}=A y_{1}=A x_{2}=A B y_{2}$, so the task at hand will turn into a look

$\pi=\left(c_{2}-p_{2}-p_{1} B-s A B\right) y_{2}-\left(q_{1}-q_{2}\right) \rightarrow \max$

$f_{1}+f_{2} \leq S-F_{1}-F_{2}$

$\left.\left(p_{1} B+s A B\right) y_{2}-k_{1} f_{1}\right) \leq k_{1} v_{1}-q_{1}$

$\left.\left(p_{2} B+c_{1} B\right) y_{2}-k_{2} f_{2}\right) \leq k_{2} v_{2}-q_{2}$

Condition (1.27) provides the specified volume of investments in fixed assets and determines the amount of investment in the current assets of the supplier and the manufacturer and is equivalent to equation (1.22). The restriction of equation (1.28) follows from formula (1.20) and takes into consideration the specified value of the supplier's working capital, equation (1.29) corresponds to the mathematical expression (1.21) and determines the allowable ratio between the manufacturer's costs in terms of value and its current assets. The solution of problem (1.26) - (1.29) determines the optimal production volume of the manufacturer $\mathrm{y} 2$ and the investment volume $\mathrm{f} 1$ and $\mathrm{f} 2$ in the working assets of the supplier and the manufacturer. After that, on the basis of relations (1.28) - (1.29), the costs of the manufacturer $\mathrm{x} 2$ are calculated, provided that the production volume of the supplier y1 is equal to the manufacturer's costs [33, p. 56].

We introduce the variable $u$, which specifies the intensity of production technology production. The intensity in this case should be understood as a relative indicator characterizing the output of the final product from the unit of costs of fixed assets and working capital for the period, then $\mathrm{y} 2=\mathrm{du} *$.

The profit of the supplier and the manufacturer at operation of the latter with intensity $\mathrm{u}$, as follows from formula (1.26) is equal to the form

$$
\begin{aligned}
& \pi=\left(c_{2}-p_{2}-p_{1} B-s A B\right) d u-\left(q_{1}+q_{2}\right) \rightarrow \max \\
& f_{1}+f_{2} \leq S-F_{1}-F_{2} \\
& \left.\left(p_{1} B+s A B\right) d u-k_{1} f_{1}\right) \leq k_{1} v_{1}-q_{1} \\
& \left.\left(p_{2}+c_{1} B\right) d u-k_{2} f_{2}\right) \leq k_{2} v_{2}-q_{2}
\end{aligned}
$$

The linear programming problem (1.30) - (1.33) regarding the intensity $u$ and investment in current assets $\mathrm{f} 1$ and $\mathrm{f} 2$ is solved analytically, as the profit increases with increasing intensity $\mathrm{u}$, which satisfies the conditions (1.30) - (1.33), is achieved with the equality of the left and the right side of each condition. From here we get that

$$
\begin{aligned}
& u^{*}=\frac{k_{2}\left(k_{1} v_{1}-q_{1}\right)+k_{1}\left(k_{2}\left(v_{2}+S-F_{1}-F_{2}\right)-q_{2}\right)}{k_{2}\left(p_{1} B+s A B\right) d+k_{1}\left(p_{2}+c_{1} B\right) d} \\
& f_{1}^{*}=\frac{\left(p_{1} B+s A B\right) d u^{*}-k_{1} v_{1}+q_{1}}{k_{1}} \\
& f_{2}^{*}=S-F_{1}-F_{2}-f_{1}^{*}
\end{aligned}
$$

The condition (1.36) is possible provided:

$o_{1}\left(v_{1}+f_{1}\right)+o_{2}\left(v_{2}+f_{2}\right)+o_{3}\left(v_{3}+f_{3}\right) \rightarrow \max$ 
In Fig. 11 graphs of the allowable intensity u of a diversified company are presented, namely the intensity of the raw material supplier and the manufacturer on the investment volume $\mathrm{f} 1$ in the working assets of the supplier and the manufacturer. The optimum value of the activity intensity of a diversified company is determined by the intersection point of these graphs.

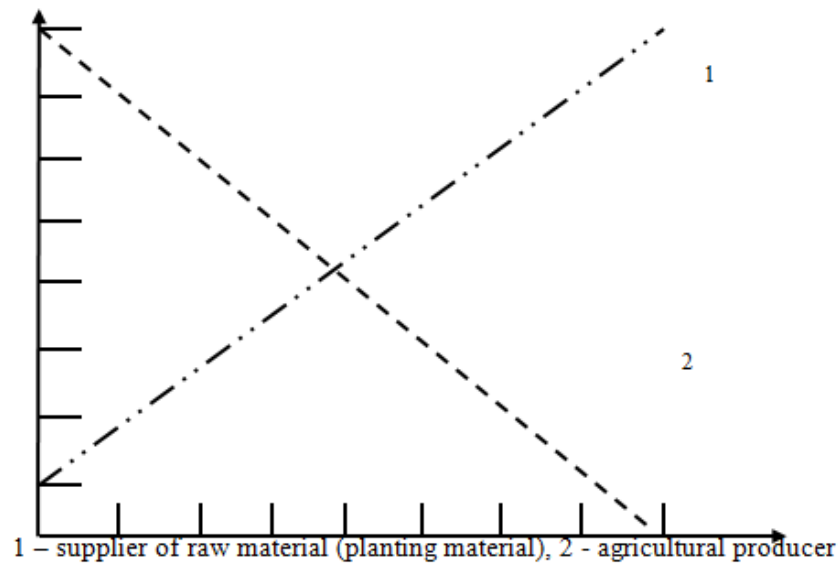

Fig. 11. Optimal value of intensity $u$ of diversified company

Source: $[33$, c. 56$]$

Therefore, the choice of the best way to penetrate the international markets of a diversified company is that in order to evaluate the synergistic effect of the marketing strategy of diversification activity are indicators of production potential and distribution system of participants of the enterprise. Indicators include prices of raw materials and finished products of the manufacturer, direct and indirect costs, the size and turnover of working capital, regulatory requirements for raw materials, manufacturer's production capabilities and demand for products in a certain foreign market. For the supplier the prices of its raw materials, direct and indirect costs, the size and turnover of the working capital of the supplier, the regulatory requirements for consumables, the production capabilities of the supplier are set.

In the case of production, the supplier of raw materials in a given ratio, the optimal intensity $\mathrm{u}^{*}$ of the diversified company will be determined by the formula (1.34), and the optimal volume of production - by the formula $y_{2}^{*}=d u^{*}$. The optimal costs $f_{1}^{*} \mathrm{i} f_{2}^{*}$ for the current assets of the supplier and the manufacturer are calculated by formulas (1.35), (1.36). If the production volume $d$ by the producer of the product at the unit intensity of its operation is unknown, the optimal production volume of the producer $y_{2}^{*}$ the optimal costs for the working assets $f_{1}^{*} \mathrm{i} f_{2}^{*}$ on the working assets of the supplier and the manufacturer are determined by task (1.30) - (1.33). Then the need for the consumables of the manufacturer of the product is determined $x_{2}^{*}=B y_{2}^{*}$; the optimal output of the supplier product is determined $y_{1}^{*}=x_{2}^{*}$, the supplier's demand for the consumables is calculated as $x_{1}^{*}=A y_{1}^{*}[33$, c. 56]. 


\section{Conclusion}

While studying the peculiarities of marketing management in the context of international business diversification, it is recognized that the ability to plan and control the marketing activities of the company in terms of diversification, the corresponding income and expenses are a prerequisite activity success. Therefore, in the process of marketing the enterprise in terms of diversification, maximum attention to planning and control should be given, since the control over the implementation of marketing annual plans, profitability control and strategic control of activity depends on the effectiveness of marketing management under the conditions of international business diversification. Thus, the above mentioned peculiarities allow us under the conditions of international diversification of the enterprise in the competitive market to identify problematic issues that arise in the course of international business diversification; to quantify and qualitatively assess and determine the degree of diversification of the enterprise in different markets, as well as conduct marketing research of the most important business segments of consumers, foreign markets and to choose the best way to reach a diversified company in the international markets.

\section{Acknowledgment}

The author would like to thank Pavlenko A. of the KNEU named after Vadym Hetman for their help and support in making this work possible. This work might not have been possible had it not been for the efforts of the prior European journal of sustainable development. Their work still lives on to some degree within European journal of sustainable development.

\section{References}

Kotler F., Keller K., Pavlenko A. (2008), Marketing Management, Kyiv. 720 p.

Voychak A., Shumeyko V. (2009), Research of modern concepts of marketing and marketing management. Marketing in Ukraine. No 4. pp. 52-55. (Ukraine).

Lamben Zh. (1996) Strategic marketing. European perspective. trans. from fr. SPb., 330 p. (Russia).

Akymtsev A. Yu. (2001), Diversification of industrial production: abstract. dis. for the degree of Ph.D.: specialty 08.00 .05 «Economics and management of the national economy (by industries and spheres of activity)». Saratov. 27 p.

Yeremina Ye.V. (2011), Organizational and methodological support for the diversification of engineering enterprises: the dissertation of the candidate of economic sciences: specialty 08.00 .05 «Economy and Management of the National Economy». V. Ivanovo.147 p.

Semenyuk O. V. (2014), Methodology of marketing effectiveness of marketing studying Methodology for studying the effectiveness of marketing activities. Economy \& State. No 6. pp. 135-136.

Yegorov Ye. N., Yeremina Ye.V. (2004), Diversification as an adaptation factor in a transformational economy. Economic problems of reliability of production systems. No 3. pp. 60-72.

Dikson Piter R. (1998), Marketing management. M.: BINOM. 228 p. (Russian).

Novitskiy Ye.G. (1999), Strategic planning in highly diversified corporate structures: on the global practice and experience of AFC «The system». REZh. №8. pp. 72-78.

Meyyer A., Mikhaylov V., Prutskov A., Tyazhov A. (2007), Industrial production diversification of: from theory to practice. M.: BINOM. 174 p. (Russian).

Voychak A. V. (1998) Marketing management. K: KNEU. 268 p. (Ukraine). 
Kovinko O. (Tanasiichuk A.), Савощенко A.C. (2008), Marketing planning is a means of achieving the goals of the processing industry. Formation of market economy: Collection of scientific works. No19. pp. 150157. (Ukraine).

Kovinko O. M., Sokolyuk K.Yu., Bomko V. D. (2015), A systematic approach to marketing planning of enterprise communication activity. Prospects for development of education and science: Collection of scientific articles. Academic Publishing House of the Agricultural University, Plovdiv, Bulgaria. pp. 310-320.

Koval'chuk S. V.(2013), Marketing strategies of innovative development of industrial enterprises: diss. D.of Economics Sciences: 08.00.04. Khmelnitsky: Khmelnytskyi National University. 510 p. (Ukraine).

Kovinko O., (2017), Designing international diversified structures of agrarian business. International scientific conference Economy and Management: Modern Transformation in the Age of Globalization, Part II, March 24. Klaipeda, Lithuania: Baltija Publishing. pp. 9-12.

Fedorchenko A. V., Okunyeva O. V. (2015), Internal marketing of the enterprise: theory, methodology, practice: monograph. Kyiv: KNEU. 230 p. (Ukraine).

Kovinko O. (Tanasiichuk A.) (2018), «Marketing mechanism of enterprise management in the conditions of international business diversifications: Dissertation for obtaining a scientific degree of the doctor of economic sciences. Available at: http://abstracts.donnu.edu.ua /article/view/5658/5684.

Kovinko O. (Tanasiichuk A.) (2017), Marketing program as a prerequisite for international diversification of agricultural enterprises of Ukraine business activities. Науковий вісник Полісся. оㅡ 2(6). pp. 97102. URL: http://nvp.stu.cn.ua/uk/component/ k2/item/741-kovin $\% \mathrm{E} 2 \% 80 \% 99 \mathrm{ko}$-O-m-asprerequisite- program-marketing-international-business-diversification-of-agricultural-enterprisesof-ukraine.html.

Tanasiichuk A., Hromova O., Abdullaieva A., Holovchuk Y., Sokoliuk K. (2019), Influence of transformational economic processes on marketing management by an international diversified conglomerate enterprise. European Journal of Sustainable Development. Italy. Vol 8, No 3. P. 448 - 454. URL: https://ecsdev.org/ojs/index.php/ejsd/article/view/898.

Tanasiichuk A., Hromova O., Abdullaieva A., Holovchuk Y., Sokoliuk K. (2019), Strategy of Internationalization by Ukrainian Meat Producers' Implementation. European Journal of

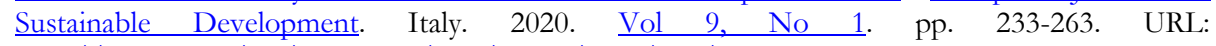
http://ecsdev.org/ojs/index.php/ejsd/article/view/990/986.

Nozdreva R. B., Tsyhychko L. Y.(1991), Marketing: how to win in the market. M.: Finance and statistics. 304 p. (Russian).

Kotler F., Bowan J., Mackenzie J. (1998), Marketing. Hospitality and tourism: Book for universities: [trans. from English.] Under. ed. N. Nostreva. M .: UNITI. 787 p. (Russian).

Haydaenko T. A.(2008), Marketing Management, 3rd ed., Revised. and supplemented by M.: Exmo. MIRBIS. 512 p. (Russian).

Pashkush N.A., Pashkush V.Yu. (2016), Strategic Marketing. M.: Yuryt Publishing House.225 p. (Russian).

Pohosyan H. R. (2003), Production Diversification of goods and services: abstract. diss. for the degree of Ph.D. Diversification of production of goods and services: abstract. diss. for the degree of Ph. D.: Special. 08.00.05. Moscow.152 p. (Russian).

Safronov N. A. (2012), Economics of the organization (enterprise). M.: Magistr: INFRA-M. 255 p. (Russian). Lysynenko I. (1999), Economic logic of conglomerate diversification. Insurance business. pp. 22-27.

Jaquemin A., Berry C. (1979), Entropy Measure of Diversification and Corporate Growth II The J. of Industrial Economics. Vol. 27. issue 4. pp. 359-69.

The Measurement of Enterprise Diversification II The Review of Economics and Statistics (1974), Vol. 56. pp. 399-401.

Hoskisson R., Hitt M. (1984), Construct Validity of an Objective Categorical Measure of Diversification Strategy. New York. pp. 215-235.

Rumelt R. (1974), Strategy, Structure and Economic Perfomance. Cambridge. P. 557-559.

Tanasiichuk A., Sirenko S. O., Serednyts'ka L. P. (2019), A systematic approach to assessing the synergistic effect of implementing a marketing strategy for international business diversification. Bulletin of Khmelnitskyi National University. Economics, 2019. No 5. pp. 233-238. (Ukraine).

Mesoeconomics transition period: markets, industries, enterprises (2001), Ed. G. B. Kleiner. M.: Science. 516 p. (Russian). 